\title{
Edukacja ewangelicznych chrześcijan w Polsce w okresie międzywojennym
}

\begin{abstract}
The Education of Evangelical Christians in Poland 1918-1939 (Edukacja ewangelicznych chrześcijan w Polsce w okresie międzywojennym)

The second half of the 19th century in Russia was marked by the emergence of an evangelical movement out of which emerged the evangelical Christians (ewangeliczni chrześcijanie). This protestant group spread gradually on Polish territory. Between WW I and WW II, there were many centres of evangelical Christians, especially on the eastern side of country. Evangelical Christians had schools with special syllabuses. In these schools they educated priests, missionaries and conductors of church choirs. These schools were also very important theological centres.
\end{abstract}

Keywords: protestants, evangelical Christians, education, theology

Szkolnictwo mniejszości religijnych w Polsce jest zagadnieniem raczej mało znanym, co zapewne wynika z dość nikłego jego wpływu na stan edukacji całego społeczeństwa. Działa ono na użytek wąskich środowisk konfesyjnych, wyjątkiem potwierdzającym regułę jest chyba tylko szkoła języka angielskiego już od okresu międzywojennego prowadzona przez metodystów ${ }^{1}$. Niemniej jest ono bardzo ciekawe, nie tylko ze względu na swoją kuriozalność. Różnego typu instytucje kształcące duchownych, misjonarzy czy działaczy mniejszości religijnych były zawsze miejscami, dzięki którym upowszechniały się w Polsce rozmaite koncepcje teologiczne, czy dzieła sztuki powstałe w krajach, w których owe mniejszości są większością. Jednakże tymi instytucjami zajmowali się jedynie historycy tych mniejszości, nader często będący jednocześnie ich przedstawicielami - w takich razach ich opracowania mają częstokroć charakter źródła. Ale nawet oni

${ }^{1}$ K. Głębowska, English Language College. Szkoła Metodystów w Warszawie, Warszawa 2002. 
rzadko poświęcali im osobną uwagę, traktując je zazwyczaj jako część struktury organizacyjnej danej grupy religijnej.

Nader interesujące instytucje kształcące stworzyły ugrupowania ewangelikalne. Oczywiście brak tu miejsca, by je bliżej scharakteryzować, zresztą na temat ewangelikalizmu wyszły niedawno dwie dość wyczerpujące monografie ${ }^{2}$. Na użytek niniejszych rozważań wystarczy tylko wyjaśnić, że są to protestanckie ugrupowania wymagające świadomej i konsekwentnej identyfikacji z zasadami doktrynalnymi swego wyznania, którą wyraża chrzest przyjęty w wieku dorosłym bądź przynajmniej jasna deklaracja. Należą do nich metodyści, baptyści, wolni chrześcijanie, zielonoświątkowcy i inni. W tym szkicu będzie mowa o przedsięwzięciach edukacyjnych ewangelicznych chrześcijan.

Ewangeliczni chrześcijanie są ugrupowaniem protestanckim powstałym w Rosji w drugiej połowie XIX w., którego zwolennikami byli przeważnie Rosjanie, choć nie tylko oni. Do tej wspólnoty przyłączali się również przedstawiciele innych narodowości, zamieszkujących imperium Romanowych, w tym także Polacy. Dwie Polki, Helena Rudzka i Anna Kurowska, które w Rosji zetknęły się z tym wyznaniem, na początku XX w. przybyły do Kowla na Wołyniu (obecnie Ukraina). Zafascynowane poznanymi poglądami religijnymi, zaczęły je głosić wśród krewnych i znajomych. W 1909 r. powstał w tym miasteczku zbór, złożony z 38 osób różnej narodowości ${ }^{3}$. Jeszcze przed wybuchem I wojny światowej, mimo trudności, ewangeliczni chrześcijanie rozwinęli działalność misyjną na Wołyniu, na Polesiu i Chełmszczyźnie. Wzmogła się ona w pierwszych latach powojennych, w efekcie czego założono wiele zborów. Wtedy też wymienione regiony znalazły się w granicach Polski.

Już w 1921 r. rozpoczęły się rozmowy ewangelicznych chrześcijan z baptystami na temat połączenia tych obydwu wyznań, bliskich pod względem doktrynalnym, w jednej organizacji kościelnej. Także w Rosji Radzieckiej, mniej więcej w tym samym czasie, prowadzono podobne rozmowy. W 1923 r. powstało Zjednoczenie Ewangelicznych Chrześcijan i Baptystów w Polsce. Ale niespełna po dwóch latach ta unia rozpadła się ${ }^{4}$. Powodem był przede wszystkim odmienny stosunek do służby wojskowej. Baptyści twierdzili, że jest ona obowiązkiem, któremu także chrześcijanie powinni sprostać. Natomiast ewangeliczni chrześcijanie uważali, że tym, którym sumienie nie pozwala brać broni do ręki, powinno się stworzyć możliwość odbycia służby bez używania oręża. Obydwie konfesje, nie mogąc się co do tych spraw zgodzić, podjęły osobną działalność. Warto zauważyć, że także w Związku Radzieckim nie doszło wtedy do zjednoczenia ewangelicznych chrześcijan i baptystów ${ }^{5}$.

2 T. J. Zieliński, Protestantyzm ewangelikalny. Studium specyfiki religijnej, Warszawa 2013; N. Modnicka, Małe światy polskiego ewangelikalizmu. Studium z antropologii interpretatywnej, Łódź 2013.

${ }^{3}$ L. Szenderowski, Ewangeliczni chrześcijanie. Ruch odrodzeniowo-reformatorski w historycznym kościele chrześcijańskim. Rys historyczny (XIX - XX w.), Warszawa 1982, s. 155-164.

${ }^{4}$ N. Modnicka, Kościół Ewangelicznych Chrześcijan w Polsce jako Kościół wyboru. Analiza etnologiczna wspólnoty religijnej, Kraków 2000, s. 133; G. Pełczyński, Ugrupowania ewangelikalne na ziemiach polskich, „Zwierciadło Etnologiczne” 2013, nr 2, s. 107.

${ }^{5}$ G. Pełczyński, Ewangelikalizm w Rosji (XIX - XX wiek), Poznań 2013, s. 147. 
Jeszcze w trakcie krótkotrwałego istnienia unii ewangelicznych chrześcijan i baptystów, przywódcy starali się o jej legalizację. Władze przyznały ją w 1927 r., kiedy pozostało w niej niewielu już baptystów. Dlatego w 1930 r. nazwę denominacji zmieniono na Związek Słowiańskich Zborów Ewangelicznych Chrześcijan w Polsce. Należy tu zwrócić uwagę na fakt, iż byli oni jedynym ugrupowaniem ewangelicznym w Polsce okresu międzywojennego mającym uregulowaną sytuację prawną.

Ewangeliczni chrześcijanie długo nie mogli utworzyć instytucji kształcącej przyszłych duchownych, nauczycieli szkół niedzielnych czy innych pracowników kościelnych. Powodem był niewątpliwie brak pieniędzy - zbory tworzyła w większości uboga ludność wiejska, zamieszkująca wschodnie, uboższe, regiony kraju. Poza tym nie mieli oni odpowiedniej kadry naukowej, która mogłaby się podjąć kształcenia „braci” pragnących oddać się służbie w zborach. Ośrodki intelektualne ewangelicznych chrześcijan znajdowały się jeszcze w latach 20. na terenie Rosji. Poza tym w okresie współpracy z baptystami korzystano z możliwości kształcenia w należącej do baptystów Szkole Biblijnej w Łodzi.

Swoją drogą Szkoła Biblijna w Łodzi działająca w latach 1907-1911 i potem w okresie międzywojennym, choć kształcąca głównie duchownych baptystycznych, odegrała istotną rolę w kształtowaniu intelektualnego oblicza polskiego ewangelikalizmu. Niewątpliwie przyczyniło się do tego stosunkowo długie trwanie tej uczelni i stała nad nią opieka ze strony niemieckich zborów baptystycznych działających w Polsce ${ }^{6}$.

Wspomnieć tu jednak trzeba przede wszystkim o innym przedsięwzięciu edukacyjnym, bo związanym z ewangelicznymi chrześcijanami, a mianowicie o Domu Misyjnym „Betel” w miejscowości Radość niedaleko Warszawy. Otóż znajdowała się tam posiadłość byłego księdza katolickiego, Wacława Żebrowskiego, po nawróceniu identyfikującego się z ugrupowaniem wolnych chrześcijan. Żebrowski postanowił zorganizować w niej szkołę. Prowadzenie jej zaproponował Mojżeszowi Gitlinowi. Gitlin był Żydem z Ukrainy, który nawrócił się podczas pobytu w Ameryce i związał się z ewangelicznymi chrześcijanami, tamże ukończył też Instytut Biblijny Moody’ego w Chicago ${ }^{7}$. Posiadał więc odpowiednie wykształcenie, aby prowadzić szkołę chrześcijańską. I szkoła ta powstała w Radości w 1923 r. Z pozostałych po niej dokumentów wynika, że była ona bardziej ośrodkiem intelektualnym niż placówką edukacyjną. Jednakże odbywały się w niej wykłady, których słuchali nie tylko ewangeliczni chrześcijanie, ale i przedstawiciele innych nurtów ewangelicznych. Ośrodek ten, zapewne ze względu na jego kierownika, był bardzo ważny dla nawróconych Żydów. „Betel” zakończył działalność na początku lat 30. XX w.

Główną formą kształcenia ewangelicznych chrześcijan były kursy. Organizowano je zwłaszcza we wschodnich dzielnicach kraju, gdzie mieściło się najwięcej zborów. Najczęściej były one przeznaczone dla pracowników kościelnych, chociaż organizowano też kursy dla wszystkich pragnących pogłębienia swego życia duchowego. Ponieważ więk-

${ }^{6}$ K. Wiazowski, Kształcenie teologiczne w Kościele Chrześcijan Baptystów w Polsce, Warszawa 2000, S. $5-12$.

${ }^{7}$ L. Szenderowski, op. cit., s. 345. 
szość ewangelicznych chrześcijan nie była Polakami, językiem wykładów nie zawsze był polski, często językiem zrozumiałych dla wszystkich był rosyjski. Wykładowcami na kursach byli najczęściej: Ludwik Szenderowski (senior), Ludwik Szenderowski (junior), Aleksy Niczyporuk, Franciszek Więckiewicz, Mojżesz Gitlin. W 1930 r. na kursie w zborze postnikowskim wykładał Włodzimierz Marcinkowski - znany intelektualista rosyjski, pochodzący z Wołynia ${ }^{8}$.

Jak twierdzi Ludwik Szenderowski (junior) ${ }^{9}$, kursy miały szczególne znaczenie w latach 20., kiedy społeczność ewangelicznych chrześcijan dopiero się organizowała, kiedy to musiała swoją tożsamość utrwalać wobec innych ugrupowań ewangelicznych, z którymi nie we wszystkich kwestiach się zgadzała.

Funkcje edukacyjne pełniła też prasa tej społeczności. Otóż w latach 1923-1925 wydawała ona wraz z baptystami miesięcznik „Wolny Chrześcijanin”, który upadł wraz z rozwiązaniem unii między obydwoma wyznaniami. W 1928 r. Ludwik Szenderowski (senior) zaczął wydawać „Zwiastun Misjonarski”, czasopismo o treściach religijnych, który ukazywał się w trzech językach: polskim, ukraińskim i rosyjskim. Po dwóch latach przedsięwzięcie to upadło z powodu trudności finansowych. Miał go zastąpić „Ewangeliczny Chrześcijanin”, periodyk polsko-rosyjski, zaadresowany do różnych kategorii czytelników, także do dzieci, lecz udało się wydać zaledwie trzy numery. Czasopismo wznowiono w 1935 r. i ukazywało się ono do końca okresu międzywojennego pod redakcją Ludwika Szenderowskiego (juniora). Ze środowiskiem ewangelicznych chrześcijan związane były jeszcze dwa periodyki wydawane przez Bolesława Goetzego: „Swiet k proswieszczeniju”, wychodzący od 1933 r. i „Droga Zbawienia”, ukazująca się od 1934.

Nie mając możliwości systematycznego kształcenia we własnej instytucji edukacyjnej, ewangeliczni chrześcijanie od 1936 r. postanowili kierować przyszłych kaznodziejów i pracowników misyjnych do Ewangelickiej Szkoły Biblijnej w Więcborku na Pomorzu, która należała do Społeczności Ewangelickiej, ugrupowania protestanckiego, z którym utrzymywali bliskie kontakty. Jednakże ta uczelnia mogła przyjąć bodaj tylko dwóch ewangelicznych chrześcijan. Poza tym, zaczęto też starać się o możliwość studiowania za granicą.

W opisywanej tu wspólnocie szczególnie dbano o wykształcenie kadry zajmującej się oprawą muzyczną nabożeństw. Prawdopodobnie wynika to z wysokiej kultury muzycznej Wołynia, gdzie znajdowała się większość zborów. Poza tym zbory na Wołyniu i w innych częściach wschodniej Polski korzystały z rozmaitych form muzycznych wypracowanych wcześniej przez współwyznawców z Rosji, a które docierały chociażby za pośrednictwem rosyjskich śpiewników ${ }^{10}$. W Związku Słowiańskich Zborów Ewangelicznych Chrześcijan w Polsce powołano oddział dyrygencki, do którego pod koniec okresu międzywojennego należało około 100 osób, a który stawiał sobie za zadanie kształcenie osób mogących uświetniać spotkania wiernych pieśnią lub grą na instrumentach. Oddział

\footnotetext{
8 Ibidem, s. 184.

9 Ibidem, s. 184.

10 Z. Pasek, Topika zbawienia w polskich kancjonałach ewangelikalnego protestantyzmu, Kraków 2004, s. 49 .
} 
organizował więc kursy dla dyrygentów chórów i zespołów instrumentalnych. Prowadził je najczęściej Ludwik Szenderowski (junior), który jako absolwent Konserwatorium w Warszawie był odpowiednią do tego osobą. Aby pomóc dyrygentom w doskonaleniu ich umiejętności, wydano nawet dwa fachowe podręczniki: Teoria muzyki i Solfegio, a także kancjonał Pieśni chwaty z nutami ${ }^{11}$.

Własną placówkę służącą celom edukacyjnym ewangeliczni chrześcijanie utworzyli dopiero pod koniec okresu międzywojennego. 1 grudnia 1937 r. rozpoczęła działalność Szkoła Biblijna w Warszawie. Jej siedziba mieściła się najpierw w mieszkaniu przy ulicy Towarowej 15, ale rok później przeniesiono ją do budynku zboru przy ulicy Szerokiej. O przyjęcie do niej mogli się ubiegać członkowie wszystkich ugrupowań ewangelicznych, a więc uczelnia ta miała charakter ekumeniczny. Świadczą o tym też jej różnowyznaniowi wykładowcy, którymi byli m.in.: Jadwiga Kunert, G. Burchardt z Kościoła Ewangelicko-Augsburskiego (luterańskiego), Martin Price z Kościoła Metodystycznego, a z ewangelicznych chrześcijan Leon Jesakow, Ludwik Szenderowski (junior) i Mojżesz Gitlin. Ten ostatni pełnił też funkcję kierownika szkoły. Nauka w tej uczelni miała trwać dwa lata. Na pierwszy rok przyjęto siedmiu studentów, w tym dwóch narodowości żydowskiej. Niestety, wybuch II wojny światowej w 1939 r. zakończył działalność szkoły. Nie mogła więc ona w pełni się rozwinąć, a przede wszystkim wykształcić absolwentów, którzy zastosowaliby w praktyce to, co dała im uczelnia. Niemniej wskazuje się na Michała Podworniaka, będącego jej wychowankiem, który stał się później wybitnym ewangelicznym pisarzem ukraińskim, działającym w Kanadzie ${ }^{12}$.

Długotrwały brak stałej placówki edukacyjnej nie może świadczyć bynajmniej na niekorzyść ewangelicznych chrześcijan. Pamiętać trzeba, że byli oni wyznaniem prawnie uznanym, nie mieliby więc większych trudności z założeniem własnej uczelni teologicznej. Jeżeli jej długo nie zakładali, to widocznie nie była ona im aż tak bardzo potrzebna. Radzono sobie bez niej, organizując doraźne, ale zdaje się bardzo solidne kursy biblijne. Ich absolwenci dobrze pracowali jako misjonarze, prezbiterzy, nauczyciele czy dyrygenci. Najlepszym dowodem na to jest stały wzrost zborów ewangelicznych chrześcijan, w których pod koniec okresu międzywojennego doliczono się ponad 11000 ochrzczonych członków.

Po wojnie ewangeliczni chrześcijanie wchodzili w skład Zjednoczonego Kościoła Ewangelicznego i korzystali z jego form edukacyjnych. Powstały po jego rozpadzie w 1988 r., Kościół Ewangelicznych Chrześcijan, kształci kadry w swoim Seminarium Biblijnym.

\footnotetext{
${ }^{11}$ N. Modnicka, op. cit., s. 140

12 L. Szenderowski, op. cit., s. 185-186.
} 
